\title{
Natural Disasters and Risk Assessment in Uttarakhand with special reference to Uttarkashi Earthquake.
}

\author{
Dr. Ranju Joshi Panday \\ Sr. Consultant, Science \\ (society for conservation integration of environment and natures co-Existence) \\ $R S \&$ GIS Institute Dheradun
}

\begin{abstract}
Uttarkashi lies in the main Alpine Himalayan belt, one of the most earthquake prone regions of the world. Crustal instability in this belt is ascribed to the movement of the Indian plate towords the Eurasian plate at the rate of about $50 \mathrm{~mm}$ per year. Besides several local faults, two prominent thrusts tending northwest to southeast, from the conspicuous tectonic features.

The basic aim of the present work is taken just one more step to make cities safer before the next disaster strikes. Development of a mitigation plan in more economic and effective in a long run than providing an ad-hoc relief after the disaster.

The earthquake caused strong ground shaking over a large area with worst effects suffered in Uttarkashi Bhatwari region. Damage was observed in unreinforced masonry buildings as well as RC frame structures. Good construction performed much better than poor quality construction. The need for RC roof and gable bands in masonry buildings was clearly underlined by the performance of buildings at the ITBP campus at Mahidanda. There was enormous loss due to landslides and collapse of retaining walls. The failure of Gawana bridge needs to be studied. This may trigger revision of the Indian code.
\end{abstract}

The earth is continually evolving and undergoing changes. From our view point at the surface of the Earth, we observe and are affected by both surface processes and the external expression of the activity occurring deep within the earth. This activity may be very slow and take place over millions of years, as in the case of a major earthquake.

Much of the large scale earth movement is concentrated along faults or breaks in the earth's crust e.g. Himalayan belt of Uttarakhand when movement occurs suddenly along a fault; energy is released in the form of an earthquake.

Earthquake consists of vertical and horizontal waves like motions of the ground. The horizontal motions cause heavy destructive forces being larger than the vertical waves say 5 to 10 times greater. They may further be along any direction.

\section{Aims And Objectives Of Present Work:}

The basic aim of the present work is taken just one more step to make cities safer before the next disaster strikes. Development of a mitigation plan in more economic and effective in a long run than providing an ad-hoc relief after the disaster.

Table : 1 District- wise House types as per MSK Classifcation

\begin{tabular}{|c|c|c|c|c|c|c|c|}
\hline $\begin{array}{l}\text { Name of } \\
\text { District } \\
\text { No. of } \\
\text { Houses }\end{array}$ & $\begin{array}{l}\text { Ares of } \\
\text { District } \\
\& \\
\text { houses } \\
(\text { Per } \\
\left.\mathrm{km}^{2}\right)\end{array}$ & $\begin{array}{l}\text { Number of } A, B, C \\
\text { type houses with } \\
\text { percentage }\end{array}$ & $\begin{array}{l}\text { Area under } \\
\text { MSK } \\
\text { Intensity } \\
\mathrm{KM}^{2}\end{array}$ & $\begin{array}{l}\text { Number } \\
\text { of houses } \\
\text { in } \\
\text { Intensity } \\
\text { Area }\end{array}$ & $\begin{array}{l}\text { Numbe } \\
r \text { a type } \\
\text { houses }\end{array}$ & $\begin{array}{l}\text { Number } \\
\text { B-type } \\
\text { houses }\end{array}$ & $\begin{array}{l}\text { Number } \\
\text { of C } \\
\text { type } \\
\text { houses }\end{array}$ \\
\hline \multirow{3}{*}{$\begin{array}{l}\text { Almora } \\
282620\end{array}$} & \multirow{3}{*}{$\begin{array}{l}5385 \\
(52.48)\end{array}$} & \multirow{3}{*}{$\begin{array}{l}\text { A } 273530(96.78 \%) \\
\text { B } 6515(2.31 \%) \\
\text { C } 2575(0.91 \%)\end{array}$} & \multirow{3}{*}{$\begin{array}{l}\text { VIII } 800 \\
\text { VII } 1300 \\
\text { VI } 3285\end{array}$} & \multirow{3}{*}{$\begin{array}{l}41986 \\
68228 \\
177406\end{array}$} & \multirow{3}{*}{$\begin{array}{l}40636 \\
66033 \\
166861\end{array}$} & \multirow{3}{*}{$\begin{array}{l}968 \\
1573 \\
3974\end{array}$} & 382 \\
\hline & & & & & & & 622 \\
\hline & & & & & & & 1571 \\
\hline \multirow{3}{*}{$\begin{array}{l}\text { Chamoli } \\
199745\end{array}$} & \multirow{3}{*}{$\begin{array}{l}9125 \\
(21.89)\end{array}$} & A $193635(96.94 \%)$ & VIII 800 & 17512 & 16976 & 110 & 426 \\
\hline & & В $1250(0.63 \%)$ & VII 1300 & 28457 & 27585 & 178 & 692 \\
\hline & & C $4860(20.43 \%)$ & VI 4600 & 100693 & 97613 & 630 & 2450 \\
\hline \multirow{3}{*}{$\begin{array}{l}\text { Dehradun } \\
254985\end{array}$} & \multirow{3}{*}{$\begin{array}{l}3088 \\
(82.57)\end{array}$} & A $89940(35.27 \%)$ & VIII 800 & 60058 & 23300 & 40170 & 2588 \\
\hline & & B $155055(60.81 \%)$ & VII 1300 & 107344 & 37863 & 65276 & 4207 \\
\hline & & C $9990(3.92 \%)$ & VI 988 & 81582 & 28776 & 49609 & 3196 \\
\hline
\end{tabular}


Natural Disasters and Risk Assessment in Uttarakhand with special reference to Uttarkashi

\begin{tabular}{|l|l|l|l|l|l|l|l|} 
Garhwal & 5440 & A 218335(86.80\%) & VIII 800 & 36990 & 32108 & 4096 & 786 \\
& $(46.24)$ & B 27855(11.08\%) & VII 1300 & 60109 & 52176 & 6657 & 1277 \\
& & C 5345(2.12\%) & VI 3340 & 154435 & 134051 & 17102 & 3282 \\
\hline $\begin{array}{l}\text { Nainital } \\
\mathbf{3 3 3 0 5 5}\end{array}$ & 6794 & A 138155(41.48\%) & VIII 800 & 39218 & 16268 & 21079 & 1871 \\
& $(49.02)$ & B 179010(53.73\%) & VII 1300 & 63729 & 26435 & 34253 & 3040 \\
& & C 15890(4.77\%) & VI 4600 & 225501 & 93540 & 121202 & 10759 \\
\hline $\begin{array}{l}\text { Pithoragar } \\
\text { h }\end{array}$ & 8856 & A 173655(93.55\%) & VIII 800 & 16768 & 15687 & 718 & 363 \\
185620 & $(20.96)$ & B 7945(4.28\%) & VII 1300 & 27248 & 25491 & 1166 & 590 \\
\hline $\begin{array}{l}\text { Tehri } \\
\text { Garhwal }\end{array}$ & 4421 & C 4020(2.17\%) & VI 4600 & 96415 & 90200 & 4127 & 2088 \\
$\mathbf{2 0 4 6 5 5}$ & $(46.29)$ & B 9060(4.43\%) & VII 1300 & 60179 & 55831 & 2664 & 1683 \\
& & C 5725(2.79\%) & VI 2321 & 107443 & 99681 & 4756 & 3006 \\
\hline $\begin{array}{l}\text { Uttarkashi } \\
\mathbf{8 8 6 3 0}\end{array}$ & 8016 & A 70500(79.54\%) & VIII 800 & 8845 & 7036 & 571 & 1238 \\
& $(11.06)$ & B 5725(6.46\%) & VII 1300 & 14374 & 11433 & 928 & 2012 \\
\hline
\end{tabular}

Note: Building Type

A. Mud and adobe houses, random stone constructions

B. Ordinary brick buildings, buildings of large blocks and Prefer type.

C. Reinforced building, well built wooden buildings

Sources; Arya, A.S; Damage scenarios of probable earthquake of M6.5 in UP, Himalaya, Himalyan Geology, Vol.20(1)

Uttarkashi Earthquake:

On October 20, 1991, at 2.53 a.m. local time, an earthquake occurred in the

Garhwal Himalaya in northern India. The earthquake caused strong ground shaking in the district of Uttarkashi, Tehri and chamoli in the state of Uttarakhand.

Uttarkashi lies in the main Alpine Himalayan belt, one of the most earthquake prone regions of the world. Crustal instability in this belt is ascribed to the movement of the Indian plate towords the Eurasian plate at the rate of about $50 \mathrm{~mm}$ per year. Besides several local faults, two prominent thrusts tending northwest to southeast, from the conspicuous tectonic features.

Figure: 1 Uttarkashi - Earthquake (October 1991) and Microseismicity in Tehri- Uttarkashi Region

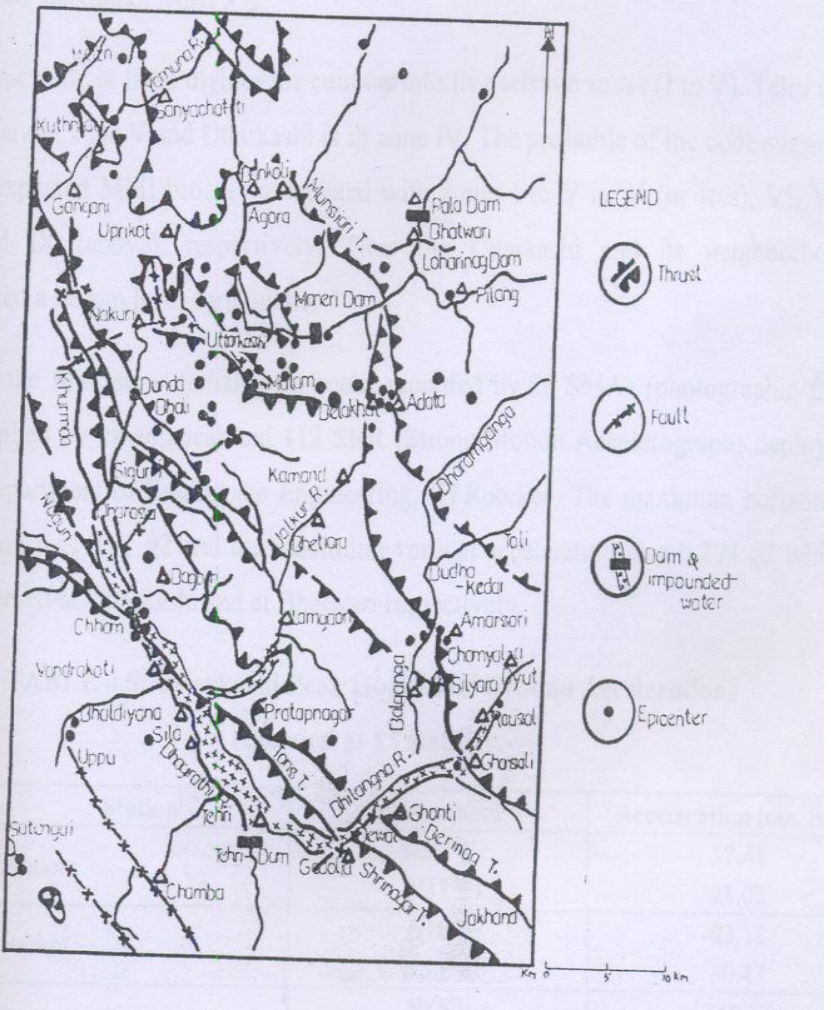

Source : Valdiya, K.s. 
This Earthquake has provided excellent strong motion records. The area is instrumented with a number of SMA's (Photo graphic film type, supplied by kinematics) and structural response recorders(SRR) operated by the university of Roorkee. Maximum horizontal acceleration of $0.03 \mathrm{~g}$ and maximum Vertical acceleration of $0.04 \mathrm{~g}$ were recorded. .

INTENSITY OF SHAKING:

The intensity of shaking was moderate. The maximum intensity was VIII on the modified mercalli (MM) scale at Budhakedar, Krishanpur, Maneri, Uttarkashi, Mahinanda and Bhatwari, Tehri, Ghansyali and Gangotri had a shaking of MMI VII.

The seismic code in India, Tehri and chamoli are in zone V and Uttarkashi is in Zone IV. This was the first major Indian earthquake recorded by 28 SMAs(Photographic film type, supplied by kinematics) and 112 SRR (Strong Motion Accelerograph) deployed by the Department of Earthquake engineering, IIT Roorkee. The maximum horizontal acceleration was $0.31 \mathrm{~g}^{2}$ and the maximum vertical acceleration was $0.294 \mathrm{~g}^{2}$ which were observed at Uttarkashi and at Bhatwari respectively.

Table 2: Uttarkashi Peak Horizontal Groung Accelerations recorded at 13 stations.

\begin{tabular}{|c|c|c|c|}
\hline Sr. No. & Station & Component & Acceleration $\left(\mathrm{cm} \cdot \mathrm{sec}^{2}\right)$ \\
\hline 1 & Almora & $\begin{array}{l}\mathrm{N} 53^{0} \mathrm{~W} \\
\mathrm{~N} 37^{0} \mathrm{E}\end{array}$ & $\begin{array}{l}17.41 \\
21.02 \\
\end{array}$ \\
\hline 2 & Barakot & $\begin{array}{l}\mathrm{N} 10^{\circ} \mathrm{E} \\
\mathrm{N} 80^{\circ} \mathrm{W}\end{array}$ & $\begin{array}{l}93.18 \\
80.47 \\
\end{array}$ \\
\hline 3 & Bhatwari & $\begin{array}{l}\mathrm{N} 85^{\circ} \mathrm{E} \\
\mathrm{N} 05^{0} \mathrm{~W}\end{array}$ & $\begin{array}{l}248.37 \\
241.89\end{array}$ \\
\hline 4 & Ghansali & $\begin{array}{l}\mathrm{N} 00^{\circ} \mathrm{E} \\
\mathrm{N} 90^{\circ} \mathrm{E}\end{array}$ & $\begin{array}{l}115.59 \\
114.89\end{array}$ \\
\hline 5 & Karnprayag & $\begin{array}{l}\text { N05 }{ }^{0} \mathrm{~W} \\
\mathrm{~N} 85^{0} \mathrm{E}\end{array}$ & $\begin{array}{l}60.99 \\
77.35\end{array}$ \\
\hline 6 & Kosani & $\begin{array}{l}\mathrm{N} 25^{\circ} \mathrm{W} \\
\mathrm{N} 65^{\circ} \mathrm{E}\end{array}$ & $\begin{array}{l}28.34 \\
31.50\end{array}$ \\
\hline 7 & Koteshewar & $\begin{array}{l}\mathrm{N} 30^{\circ} \mathrm{W} \\
\mathrm{N} 60^{0} \mathrm{E}\end{array}$ & $\begin{array}{l}98.85 \\
65.23 \\
\end{array}$ \\
\hline 8 & Koti & $\begin{array}{l}\mathrm{N} 10^{\circ} \mathrm{E} \\
\mathrm{N} 80^{\circ} \mathrm{W}\end{array}$ & $\begin{array}{l}20.64 \\
40.95\end{array}$ \\
\hline 9 & Purola & $\begin{array}{l}\mathrm{N} 65^{\circ} \mathrm{W} \\
\mathrm{N} 25^{0} \mathrm{E}\end{array}$ & $\begin{array}{l}73.95 \\
91.68 \\
\end{array}$ \\
\hline 10 & Rudraprayag & $\begin{array}{l}\mathrm{N} 53^{0} \mathrm{E} \\
\mathrm{N} 37^{0} \mathrm{~W}\end{array}$ & $\begin{array}{l}52.29 \\
50.67\end{array}$ \\
\hline 11 & Srinagar & $\begin{array}{l}\mathrm{N} 50^{\circ} \mathrm{W} \\
\mathrm{N} 40^{\circ} \mathrm{E}\end{array}$ & $\begin{array}{l}65.44 \\
49.44\end{array}$ \\
\hline 12 & Tehri & $\begin{array}{l}\mathrm{N} 65^{0} \mathrm{~W} \\
\mathrm{~N} 27^{0} \mathrm{E}\end{array}$ & $\begin{array}{l}71.41 \\
61.13\end{array}$ \\
\hline 13 & Uttarkashi & $\begin{array}{l}\mathrm{N} 15^{0} \mathrm{~W} \\
\mathrm{~N} 75^{0} \mathrm{E}\end{array}$ & $\begin{array}{l}237.27 \\
303.99\end{array}$ \\
\hline
\end{tabular}

Source- Chandrasekran and Das, 1995

BUILDINGS DAMAGE:-

Damage to rural dwellings (random rubble stone masonry supporting a heavy root) was extensive in areas of maximum shaking. In developed areas, most privately owned buildings and older government owned buildings were build without seismic provisions.

Table - 3 Damages

\begin{tabular}{|c|c|c|c|c|c|c|c|}
\hline \multirow[t]{2}{*}{ District } & \multirow{2}{*}{$\begin{array}{l}\text { Village } \\
\text { Affected }\end{array}$} & \multirow{2}{*}{$\begin{array}{l}\text { Population } \\
\text { Affected (in } \\
\text { lacs) }\end{array}$} & \multicolumn{2}{|c|}{ Damage Houses } & \multicolumn{2}{|c|}{ Lives lost } & \multirow{2}{*}{$\begin{array}{l}\text { Injuries } \\
\text { Persons }\end{array}$} \\
\hline & & & Fully & Partially & Human & Cattles & \\
\hline Uttarkashi & 601 & 2.50 & 14847 & 19811 & 650 & 562 & 4710 \\
\hline $\begin{array}{l}\text { Tehri } \\
\text { Garhwal }\end{array}$ & 605 & 1.00 & 4730 & 21954 & 63 & 71 & 43 \\
\hline Chamoli & 699 & 0.72 & 573 & 1973 & 2 & 10 & 18 \\
\hline
\end{tabular}


Natural Disasters and Risk Assessment in Uttarakhand with special reference to Uttarkashi

\begin{tabular}{|l|l|l|l|l|l|l|l|}
\hline Dehradun & 116 & 0.02 & 26 & 452 & - & 9 & - \\
\hline $\begin{array}{l}\text { Pauri } \\
\text { Garhwal }\end{array}$ & 72 & 0.01 & 34 & 449 & - & 5 & 3 \\
\hline Nainital & - & - & 2 & 4 & - & - & - \\
\hline Total & 2093 & 4.25 & 20212 & 44643 & 715 & 657 & 4774 \\
\hline
\end{tabular}

Source- Department of Revenue and Relif, U.P. Govt., 94

Table-4 Destruction caused by the Garhwal Oct. 20,1991

\begin{tabular}{|l|l|}
\hline Affected Districts & Uttarkashi, Tehri, Rudraprayag and Chamoli \\
\hline Persons killed & Around 800 \\
\hline Injured & 5000 Approx \\
\hline Affected villages & 2000 \\
\hline Affected population & 4.5 lakh \\
\hline Totally Collapsed houses Semi collapsed with cracks & $25000+$ \\
\hline Useless for living & $75000+$ \\
\hline Collapsed School/ Inter colleges & 630 \\
\hline Animals killed & $4000+$ \\
\hline Total Loss & Rs. $370+$ Crores \\
\hline
\end{tabular}

Source- Himalaya Today Dec. 91-May 92

Uttarkashi has a number of three and four story reinforced concrete (RC) framed buildings which sustained damage. Photo(1) shows the state Bank building in Uttarkashi. During the earthquake, the upper two stories collapsed on the first story. Informations from the local residents revealed that the building was first constructed as one story only, the upper two stories were added subsequently. The beams has only two normal rebars on the top face near the column joint and those were incorrectly placed.

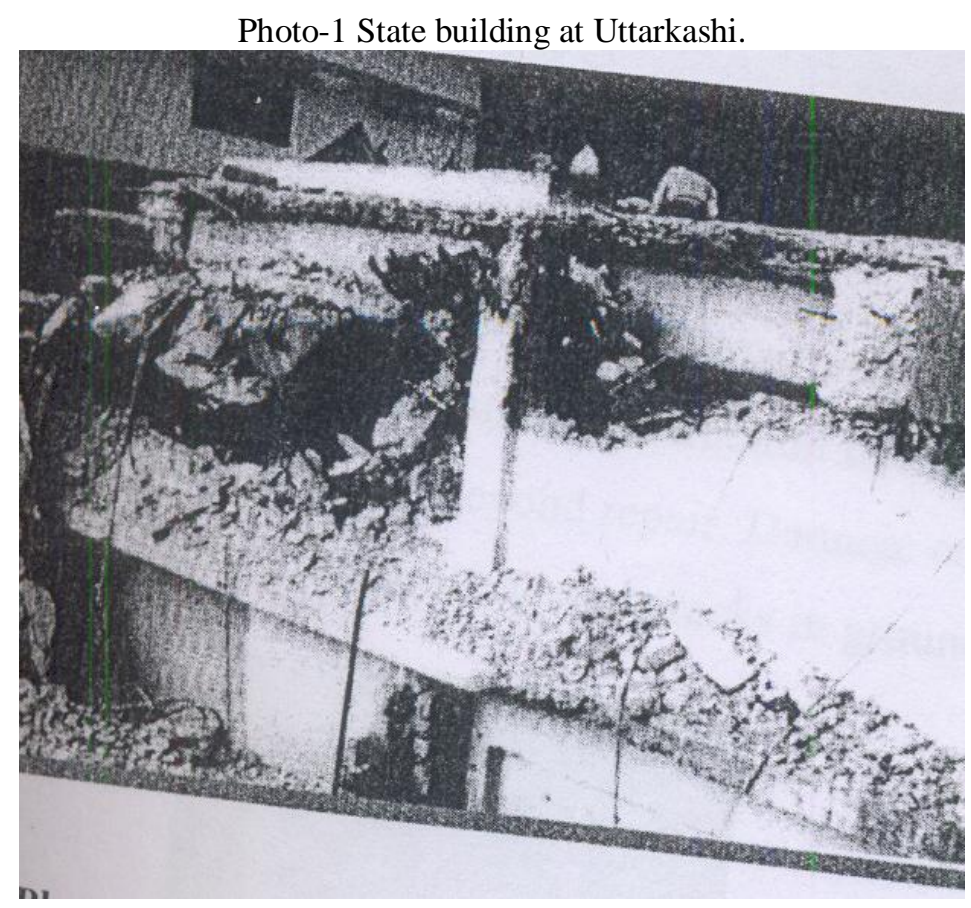

Most government buildings are one or two story buildings with load bearing walls and sloping roofs. Older construction is of unreinforced random rubble stone masonry which performed very poorly. The newer construction is of unreinforced concrete block masonry and usually include a RC band at lintel level.

The Maneri Hydel Power project colony campus has two-storey buildings with concrete block masonry bearing walls of poorer quality construction. Many buildings were damaged beyond repair. Damage consisted of (I) severe damage to gable walls photo 2 and (ii) diagonal cracks in ground story walls. 


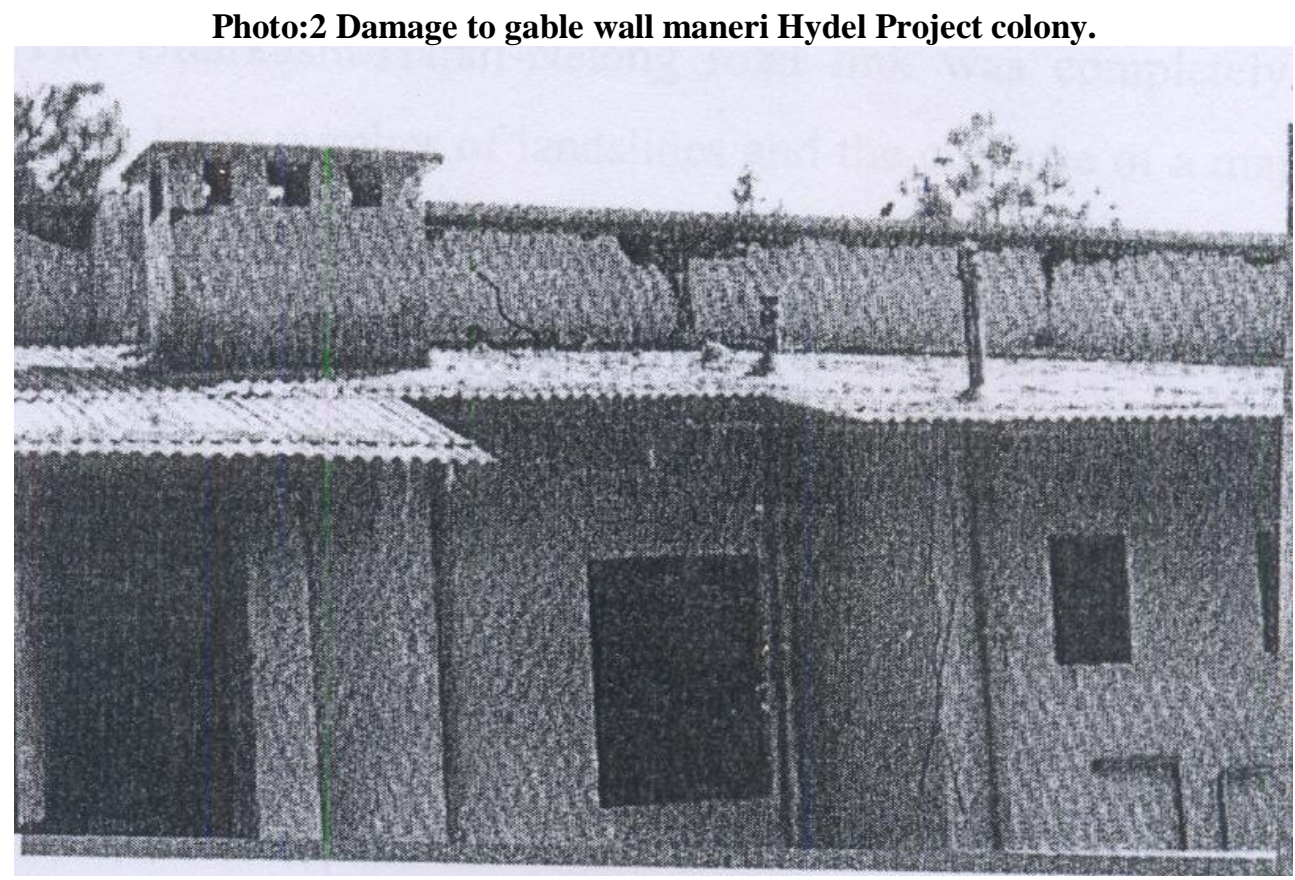

The ITBP Paramiliatry campus at Mahidanda consists a large number of two story residential buildings with load bearing walls of concerete masonry. All have RC lintel bands, but no roof bands or gable bands. The construction is about 10 years old. The damage to buildings consisted of (i) diagonal cracks below window sills, (ii) damage at the connection between masonry walls and RC roof slabs, (iii) in buildings with corrugated iron sheet roofs, damage at seat of purlings on the gable end walls and (iv) damage to walls supporting roofs at different heights at either end(Photo 3). Roof and gable bands would have prevented damage of types (ii), (iii) and (iv) .

Photo 3 Damage to wall supporting split level roof - ITBP Campus, Mahidanda.

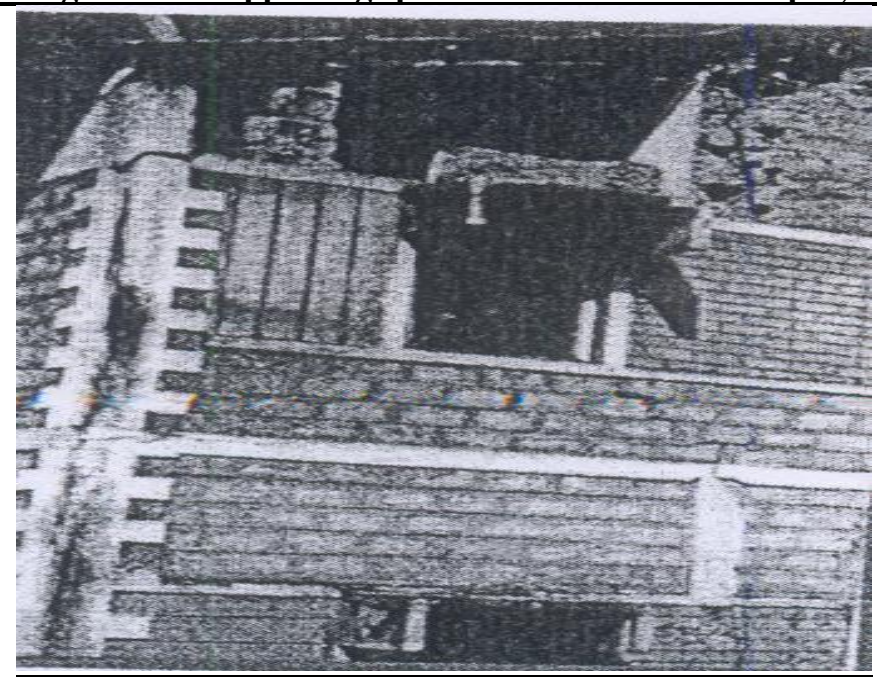

DAMAGE ASSESSMENT OF ROADS:-

Roads in the area were extensively damaged due to failure of slopes, retaining walls, and bridges. The Uttarkashi Harsil Nelong road link was completely distrupted for several days due to large number of landslides and the collapse of a major bridge.

Numerous massive landslides took place on the Uttarkashi- Harsil road, particularly on a $42 \mathrm{~km}$ stretch between Uttarkashi and Bhatwari. The stretch is believed to be the area of most intense shaking.

On the Uttarkashi-Lumgaon route the approach road to a bridge near the village of Kishanpur is on an embankment about $8.0 \mathrm{~m}$ high with retaining walls in "banded" stone masonry. The walls on both sides of the approach road collapsed leading to failure of the embankment. 
The Gawana Bridge is a 56.0m. span steel truss bridge build in 1974 and located at $6 \mathrm{Km}$. from Uttarkashi towards maneri. The entire bridge came off the abutments and fell into river (Photo 4) causing the entire area beyond Uttarkashi to be cut off from the rest of the country Inadequate design of the bearings and anchor bolts as well as absence of any suitable means of preventing the span from falling of the supports were responsible for the damage.

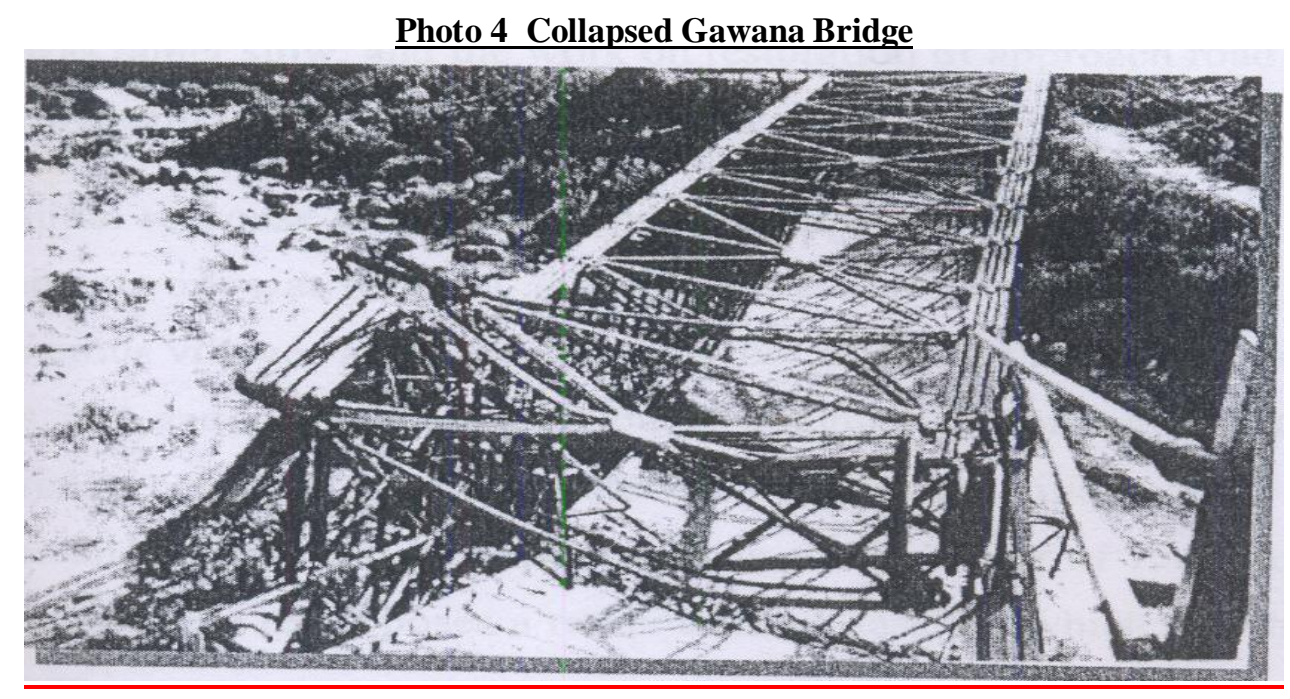

The area has a number of pedestrian suspension bridges that cross the river Bhagirathi. The main tower and the anchors blocks are of unreinforced stone masonry. Five of these bridges were damaged, four of them in the maneri Bhatwari region. Cracks in the tower and anchor blocks were typical of damage sustained.

The peak horizontal ground acceleration in the region was about $0.30 \mathrm{~g}$. The Indian codes specifies the design seismic force for bridges in the range of 0.05 to $0.075 \mathrm{~g}$ for zone IV. This is obviously inadequate. It is hoped that the bridge failures caused by this earthquake will provide the necessary impetus to revise the code.

\section{CONCLUSIONS:}

The earthquake caused strong ground shaking over a large area with worst effects suffered in Uttarkashi Bhatwari region. Damage was observed in unreinforced masonry buildings as well as RC frame structures. Good construction performed much better than poor quality construction. The need for RC roof and gable bands in masonry buildings was clearly underlined by the performance of buildings at the ITBP campus at Mahidanda. There was enormous loss due to landslides and collapse of retaining walls. The failure of Gawana bridge needs to be studied. This may trigger revision of the Indian code.

\section{ACKNOWLEDGEMENT}

The present work is a result of guidance, assistance and supervision provided to me by my supervisor Dr. R.K.Pande, Professor, D.S.B. campus Kumoun University Nainital, Uttarakhand who assisted me in different aspects of the proposal in several ways despite his very busy schedule.

Thanks are due to my mother, my husband Sanjay Pandey (Director, Siddharth IAS, Haldwani) and my brother Ashu Joshi (Advocate) for their cooperation in different stages.

I take this opportunity of expressing my deep gratitude to my sisters, brother-in-laws, for their valuable assistance and moral support.

\section{References:-}

[1]. Arya, A.S. (1999); Damage scenario of probable Earthquakes of M 6.5 in UP Himalaya, Himalyan Geology, Vol. 20(1), University of Roorkee, Roorkee.

[2]. Arya, A.S. Mandal, G.S. Thakur, V.C. Prem Krishna, Lakshmanan, N. Chaudhuri, S.K., Gupta, T.N. (1997) Vulnerability Atlus of India, Building Materials and Technology promotion council, Ministry of urban Development Govt. of India, New Delhi.

[3]. Bose, P.R, Arya, A.S. and Chandra, B., (1989): suggestions for earthquake resistant construction of buildings under Indira Awas Yojana in east India, workshop on low cost housing in respect of Indira Awas Yojna, Imphal.

[4]. Carter, W.Nick(1992): Disaster Management A Disasters Managers Handbook, Asian Development Bank, Manila, Philippines.

[5]. Sanwal Dhriti(2002) Disaster management in Higher Uttranchal Himalya with special Reference to Malpa, Okhimath, Uttarkashi and Chamoli disaster, unpub. Thesis kumoun university Nainital, Uttarakahnd, India 